\title{
PERKEMBANGAN KULTUR DAUN Aglaonema sp. var Siam Pearl, Aglaonema sp. var. Lady Valentin dan Aglaonema sp. var. Lipstik DENGAN PERLAKUAN ZAT PENGATUR TUMBUH IAA DAN BAP
}

\author{
Ika Sukma Dewi, Dwi Kusuma Wahyuni, dan Hery Purnobasuki \\ Departemen Biologi, Fakultas Sains dan Teknologi Universitas Airlangga \\ E-mail: kusumaanwar@yahoo.com
}

\begin{abstract}
The aim of this research was to know the effect of 3-indole-acetic acid (IAA) and 6-bensilaminopurine (BAP) and optimum concentration of IAA+BAP toward growth and development of the leaf culture of Aglaonema sp. var. Siam Pearl, Aglaonema sp. var. Lady Valentine, and Aglaonema sp. var. Lipstik. The explants were taken from the leaf. The explants were cultured in solid MS medium with addition various concentration of IAA 0,5 $\mathrm{mg} / \mathrm{l}, 2 \mathrm{mg} / \mathrm{l}, 3 \mathrm{mg} / \mathrm{l}, 5 \mathrm{mg} / \mathrm{l}$, and $8 \mathrm{mg} / \mathrm{l}$ and BAP $5 \mathrm{mg} / \mathrm{l}$. Observation had been conducted for 16 weeks to know the response the development of explants leaves such as the periphery of explants coloured of brown, leaves explants of arch shaped, the colour of explants to change for pale, and to form callus. The data were include of the number of explants which able to form callus, time of callus formation, the colour and texture callus, and stage of development explants were analyzed descriptively. The result of 16 weeks observation showed that the addition of IAA and BAP on the leaves explants to give the different effects. Aglaonema sp. var. Lipstik can form callus by treatment of $5 \mathrm{mg} / \mathrm{l}$ IAA:5mg/l BAP, and $8 \mathrm{mg} / \mathrm{l} I A A: 5 \mathrm{mg}$ BAP. The colour of callus are clear, the shape of globular, with friable textures.
\end{abstract}

Keywords: Aglaonema sp., 6-bensilaminopurine, callus induction, 3-indole-acetic acid

\section{PENGANTAR}

Tanaman Aglaonema merupakan tanaman hias primadona di Indonesia. Tanaman ini juga dikenal sebagai ratu tanaman hias karena habitusnya anggun sehingga mempunyai nilai ekonomi tinggi (Subono dan Andoko, 2004). Upaya budidaya Aglaonema terus diupayakan untuk memenuhi kebutuhan pasar. Perbanyakan Aglaonema $s p$. secara kultur jaringan dapat memberikan solusi bagi permasalahan yang muncul akhir-akhir ini, misalnya terbatasnya jumlah tanaman indukan, mahalnya harga jual bibit, pertumbuhan tergantung musim serta rendahnya kualitas dan kuantitas bibit yang dihasilkan melalui stek batang maupun cangkok.

Dengan kultur jaringan, dapat diperoleh bibit tanaman Aglaonema sp. dalam keadaan seragam melalui induksi morfogenesis somatik baik melalui direct morphogenesis maupun indirect morphogenesis (George and Sherington, 1992). Perkembangan beberapa dekade terakhir teknik kultur jaringan digunakan untuk mengexploitasi variasi somaklonal untuk menciptakan varietas-varietas baru (Akbar et al., 2003; Islam et al., 2005) sehingga aplikasinya pada tanaman hias seperti Aglaonema sp. bertujuan untuk mendapatkan varietas-varietas cantik. Pada indirect morphogenesis dapat menyebabkan somaklonal variasi yang menyediakan karakter tanaman yang diinginkan berupa varietas baru (Akbar et al., 2003).
Keberhasilan kultur jaringan untuk mengeksploitasi somaklonal variasi dipengaruhi genotipe tanaman (Bai dan Qu, 2000; Tripathy dan Reddy, 2002; Shirin et al., 2007), medium (Abadi dan Kaviani, 2010), zat pengatur tumbuh (Syahid dan Kristina, 2007; Hoesen et al., 2008; Jahan et al., 2009; Sari, 2010), dan fase perkembangan eksplan (Islam et al., 2005; Ibrahim et al., 2010; Reddy et al., 2011). Sedangkan untuk induksi kalus embriogenik, genotype tanaman dan komposisi medium adalah faktor penting penentu keberhasilan (Rachmawati et al, 2004). Pengaruh variasi genotipe signifikan telah dilaporkan pada padi Japonica dan Indica (Rashid et al., 2009; Khana and Raina, 1998 dalam Rachmawati and Anzai, 2006), pada Festuca arundinacea Schreb. (Bai dan Qu, 2000), pada kapas India (Tripathy dan Reddy, 2002) dan pada padi Jawa (Rachmawati dan Anzai, 2006).

Produksi kalus dan regenerasinya adalah tahapan penting untuk pemuliaan tanaman melalui rekayasa genetik dan eksploitasi variasi somaklonal. Oleh karena itu perlu dilakukan penelitian mengenai induksi kalus daun Aglaonema sp. var Siam Pearl, Aglaonema sp. var Lady Valentin dan Aglaonema sp. var Lipstik dengan penambahan zat pengatur tumbuh. Penelitian ini dilakukan untuk mengetahui pengaruh variasi genotipe dan konsentrasi hormon IAA dan BAP terhadap pertumbuhan, perkembangan dan induksi kalus eksplan daun Aglaonema sp. var Siam 
Pearl, Aglaonema sp. var Lady Valentin dan Aglaonema $s p$. var Lipstik.

\section{BAHAN DAN CARA KERJA}

Penelitian ini dilaksanakan bulan Februari sampai bulan Juni 2009 di Laboratorium Fisiologi Tumbuhan, Departemen Biologi, Fakultas Sains dan Teknologi, Universitas Airlangga Surabaya. Bahan eksplan yang digunakan adalah daun Aglaonema sp. var. Siam Pearl, Aglaonema sp. var. Lady Valentine, dan Aglaonema sp. var. Lipstik. Bahan kimia yang digunakan meliputi alkohol $70 \%$, $\mathrm{HCl} 1 \mathrm{~N}, \mathrm{KOH} 1 \mathrm{~N}$, Clorox 10\% dan 20\%, aquades steril, spiritus dan bahan kimia penyusun media pertumbuhan Murashige dan Skoog (MS) (Murashige and Skoog, 1962), zat pengatur tumbuh IAA (3-indole-acetic acid) dan BAP (6-benzylaminopurine).

Dalam penelitian ini digunakan perlakuan kombinasi zat pengatur tumbuh IAA dan BAP. Kosentrasi hormon IAA yang digunakan adalah $0,5 \mathrm{mg} / 1 ; 2 \mathrm{mg} / 1 ; 3 \mathrm{mg} / 1$, $5 \mathrm{mg} / \mathrm{l} ; 8 \mathrm{mg} / \mathrm{l}$ ) dan BAP $5 \mathrm{mg} / \mathrm{l}$ dengan perbadingan IAA: $\mathrm{BAP}=0,5 \mathrm{mg} / \mathrm{l}: 0,5 \mathrm{mg} / \mathrm{l}$ (MS1); $2 \mathrm{mg} / \mathrm{l}: 0,5 \mathrm{mg} / \mathrm{l}$ (MS); $3 \mathrm{mg} / \mathrm{l}: 0,5 \mathrm{mg} / \mathrm{l}$ (MS3); $5 \mathrm{mg} / \mathrm{l}: 0,5 \mathrm{mg} / \mathrm{l}$ (MS4); dan $8 \mathrm{mg} / \mathrm{l}$ : 0,5 mg/l (MS5). Variasi genotipe Aglaonema yang digunakan adalah Aglaonema sp. var. Siam Pearl, Aglaonema sp. var. Lady Valentine, dan Aglaonema $s p$. var. Lipstik. Medium yang digunakan adalah medium MS padat, sukrosa 3\%, pH $5,6-5,8$, agar $8 \%$. Media disterilkan dengan autoclave pada tekanan $1,2 \mathrm{~atm} 121^{\circ} \mathrm{C}$ selama 20 menit.

Eksplan disterilkan dengan cara menggunakan larutan Clorox 20\% dan Clorox 10\% sambil menggoyang-goyang selama 7 menit. Setelah itu membuang larutan Clorox dan membilasnya dengan aquades steril sebanyak 3 kali. Meletakkan eksplan daun Aglaonema sp. ke dalam cawan petri berisi vitamin $\mathrm{C}$ dan memotong daun Aglaonema sp. dengan ukuran kurang lebih $1 \mathrm{~cm}^{2}$. Tiap potongan, bagian tepinya dilukai kemudian menanamnya ke dalam media MS dengan kombinasi IAA dan BAP. Kemudian menutup botol kultur rapat-rapat, setelah itu meletakkannya di dalam ruang inkubator dengan suhu $25^{\circ} \mathrm{C}$, cahaya neon 20 watt.

Parameter yang diamati dalam penelitian ini meliputi tahap perkembangan eksplan, jumlah eksplan yang membentuk kalus, waktu terbentuknya kalus, serta morfologi kalus (warna dan tekstur kalus).
HASIL

\section{Perkembangan Eksplan Daun Aglaonema sp. var. Siam Pearl, Aglaonema sp. var. Lady Valentine, dan Aglaonema sp. var. Lipstik selama 16 Minggu}

Determinasi tahapan-tahapan perkembangan eksplan daun mengacu pada penelitian Rachmawati (2008) seperti tercantum pada Tabel 1 .

\section{Perkembangan Eksplan Daun Aglaonema sp. var. Siam Pearl selama 16 minggu}

Perkembangan eksplan daun Aglaonema sp. var. Siam Pearl selama 16 minggu menunjukkan variasi perkembangan yang beragam. Pada minggu ke-16 perlakuan MS1 dan MS2 eksplan daun berkembang melengkung, warna eksplan daun tetap, belum terbentuk kalus, tepi eksplan daun berwarna

Tabel 1. Tahapan-tahapan perkembangan eksplan daun dari seluruh perlakuan dan ciri-ciri dari masing-masing tahapan (Rachmawati, 2008)

\begin{tabular}{|c|c|}
\hline $\begin{array}{c}\text { Tahapan } \\
\text { Perkembangan }\end{array}$ & Ciri-ciri \\
\hline 0 & $\begin{array}{l}\text { Eksplan daun belum ada perkembangan, } \\
\text { permukaan eksplan daun rata, warna eksplan } \\
\text { daun tetap,belum terbentuk kalus, tepi eksplan } \\
\text { daun berwarna coklat }\end{array}$ \\
\hline 1 & $\begin{array}{l}\text { Eksplan daun sedikit melengkung, permukaan } \\
\text { eksplan daun rata, warna eksplan daun tetap, } \\
\text { belum terbentuk kalus, tepi eksplan daun } \\
\text { berwarna coklat }\end{array}$ \\
\hline $2 a$ & $\begin{array}{l}\text { Eksplan daun melengkung, warna eksplan } \\
\text { daun tetap, belum terbentuk kalus, tepi eksplan } \\
\text { daun berwarna coklat }\end{array}$ \\
\hline $2 b$ & $\begin{array}{l}\text { Eksplan daun melengkung, warna eksplan } \\
\text { daun berubah menjadi lebih tua atau lebih } \\
\text { muda, tepi eksplan daun berwarna coklat, } \\
\text { belum terbentuk kalus }\end{array}$ \\
\hline $3 a$ & $\begin{array}{l}\text { Eksplan daun melengkung atau menggulung, } \\
\text { warna eksplan daun tetap, belum terbentuk } \\
\text { kalus, tepi daun eksplan berwarna coklat }\end{array}$ \\
\hline $3 b$ & $\begin{array}{l}\text { Eksplan daun melengkung atau menggulung, } \\
\text { warna eksplan daun berubah menjadi lebih } \\
\text { tua atau lebih muda, terbentuk kalus pada } \\
\text { tepi daun }\end{array}$ \\
\hline 4 & $\begin{array}{l}\text { Eksplan daun melengkung atau menggulung, } \\
\text { warna daun tetap, bagian tengah daun berwarna } \\
\text { hijau/coklat/kuning }\end{array}$ \\
\hline
\end{tabular}


coklat (2a) sedangkan pada perlakuan MS3, MS4 dan MS5 eksplan daun berkembang melengkung atau menggulung, warna eksplan daun tetap, belum terbentuk kalus, tepi daun eksplan berwarna coklat (3a) (Tabel 2, Gambar 1).

Perkembangan eksplan daun mulai minggu pertama hingga minggu ke-16 dimulai tahap 0 , tahap 1 , tahap 2a, dan tahap 3a (Gambar 1).

\section{Perkembangan eksplan daun Aglaonema sp. var. Lady Valentine selama 16 minggu}

Perkembangan eksplan daun Aglaonema sp. var. Lady Valentine selama 16 minggu menunjukkan variasi perkembangan yang beragam. Pada minggu ke-16 perlakuan MS1 eksplan daun berkembang sedikit melengkung, permukaan eksplan daun rata, warna eksplan daun tetap, belum terbentuk kalus, tepi eksplan daun berwarna coklat (1). Pada perlakuan MS2 dan MS3 eksplan daun berkembang melengkung, warna eksplan daun tetap, belum terbentuk kalus, tepi eksplan daun berwarna coklat (2a) sedangkan pada perlakuan MS4 dan MS5 eksplan daun berkembang melengkung atau menggulung, warna eksplan daun tetap, belum terbentuk kalus, tepi daun eksplan berwarna coklat (3a) (Tabel 3, Gambar 2).

Perkembangan eksplan daun mulai minggu pertama hingga minggu ke-16 dimulai tahap 0 , tahap 1, tahap 2a, dan tahap 3a (Gambar 2).

\section{Perkembangan eksplan daun Aglaonema sp. var. Lipstik selama 16 minggu}

Perkembangan eksplan daun Aglaonema sp. var. Lipstik selama 16 minggu menunjukkan variasi perkembangan yang beragam. Pada minggu ke-16 perlakuan MS1 eksplan daun berkembang melengkung, warna eksplan daun tetap, belum terbentuk kalus, tepi eksplan daun berwarna coklat (2a). Pada perlakuan MS2 eksplan daun berkembang melengkung, warna eksplan daun berubah menjadi lebih

Tabel 2. Modus perkembangan eksplan daun Aglaonema sp. var. Siam Pearl selama 16 minggu pada berbagai perlakuan zat pengatur tumbuh 3-indole-acetic acid dan 6-benzylaminopurine $(\mathrm{n}=3)$.

\begin{tabular}{ccccccccccccccccc}
\hline \multirow{2}{*}{ Perlakuan } & \multicolumn{10}{c}{ Tahap perkembangan eksplan daun selama 16 minggu masa kultur (minggu ke-) } \\
\cline { 2 - 14 } & $\mathbf{1}$ & $\mathbf{2}$ & $\mathbf{3}$ & $\mathbf{4}$ & $\mathbf{5}$ & $\mathbf{6}$ & $\mathbf{7}$ & $\mathbf{8}$ & $\mathbf{9}$ & $\mathbf{1 0}$ & $\mathbf{1 1}$ & $\mathbf{1 2}$ & $\mathbf{1 3}$ & $\mathbf{1 4}$ & $\mathbf{1 5}$ & $\mathbf{1 6}$ \\
\hline MS 1 & 0 & 0 & 1 & 1 & 1 & 1 & 1 & $2 \mathrm{a}$ & $2 \mathrm{a}$ & $2 \mathrm{a}$ & $2 \mathrm{a}$ & $2 \mathrm{a}$ & $2 \mathrm{a}$ & $2 \mathrm{a}$ & $2 \mathrm{a}$ & $2 \mathrm{a}$ \\
MS 2 & 0 & 0 & 1 & 1 & 1 & 1 & 1 & 1 & $2 \mathrm{a}$ & $2 \mathrm{a}$ & $2 \mathrm{a}$ & $2 \mathrm{a}$ & $2 \mathrm{a}$ & $2 \mathrm{a}$ & $2 \mathrm{a}$ & $2 \mathrm{a}$ \\
MS 3 & 0 & 0 & 1 & 1 & 1 & 1 & 1 & $2 \mathrm{a}$ & $2 \mathrm{a}$ & $2 \mathrm{a}$ & $2 \mathrm{a}$ & $2 \mathrm{a}$ & $2 \mathrm{a}$ & $2 \mathrm{a}$ & $3 \mathrm{a}$ & $3 \mathrm{a}$ \\
MS 4 & 0 & 1 & 1 & 1 & 1 & 1 & $2 \mathrm{a}$ & $2 \mathrm{a}$ & $2 \mathrm{a}$ & $2 \mathrm{a}$ & $2 \mathrm{a}$ & $3 \mathrm{a}$ & $3 \mathrm{a}$ & $3 \mathrm{a}$ & $3 \mathrm{a}$ & $3 \mathrm{a}$ \\
MS 5 & 0 & 0 & 1 & 1 & 1 & 1 & $2 \mathrm{a}$ & $2 \mathrm{a}$ & $2 \mathrm{a}$ & $2 \mathrm{a}$ & $2 \mathrm{a}$ & $2 \mathrm{a}$ & $3 \mathrm{a}$ & $3 \mathrm{a}$ & $3 \mathrm{a}$ & $3 \mathrm{a}$ \\
\hline
\end{tabular}
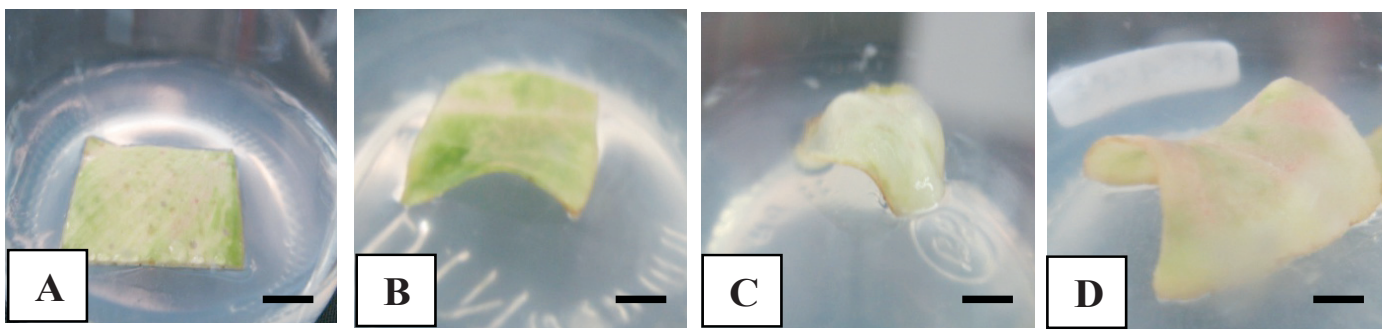

Gambar 1. Tahap perkembangan eksplan daun Aglaonema sp. var. Siam Pearl. A.Tahap 0; B. Tahap 1; C. Tahap 2a; D. Tahap 3a. Skala $0,36 \mathrm{~cm}$.

Tabel 3. Modus perkembangan eksplan daun Aglaonema sp. var. Lady Valentine selama 16 minggu pada berbagai perlakuan zat pengatur tumbuh 3-indole-acetic acid dan 6-benzylaminopurine $(n=3)$.

\begin{tabular}{|c|c|c|c|c|c|c|c|c|c|c|c|c|c|c|c|c|}
\hline \multirow{2}{*}{ Perlakuan } & \multicolumn{16}{|c|}{ Tahap perkembangan eksplan daun selama 16 minggu masa kultur (minggu ke-) } \\
\hline & 1 & 2 & 3 & 4 & 5 & 6 & 7 & 8 & 9 & 10 & 11 & 12 & 13 & 14 & 15 & 16 \\
\hline MS 1 & 0 & 0 & 0 & 1 & 1 & 1 & 1 & 1 & 1 & 1 & 1 & 1 & 1 & 1 & 1 & 1 \\
\hline MS 2 & 0 & 1 & 1 & 1 & 1 & 1 & 1 & 1 & 1 & $2 a$ & $2 a$ & $2 a$ & $2 a$ & $2 a$ & $2 a$ & $2 a$ \\
\hline MS 3 & 0 & 0 & 1 & 1 & 1 & 1 & 1 & 1 & 1 & 1 & $2 a$ & $2 a$ & $2 a$ & $2 a$ & $2 a$ & $2 a$ \\
\hline MS 4 & 0 & 1 & 1 & 1 & 1 & 1 & $2 a$ & $2 a$ & $2 a$ & $2 a$ & $2 a$ & $2 a$ & $3 a$ & $3 a$ & $3 a$ & $3 a$ \\
\hline MS 5 & 0 & 0 & 1 & 1 & 1 & 1 & 1 & 1 & $2 a$ & $2 a$ & $2 a$ & $2 a$ & $2 a$ & $2 a$ & $2 a$ & $2 a$ \\
\hline
\end{tabular}



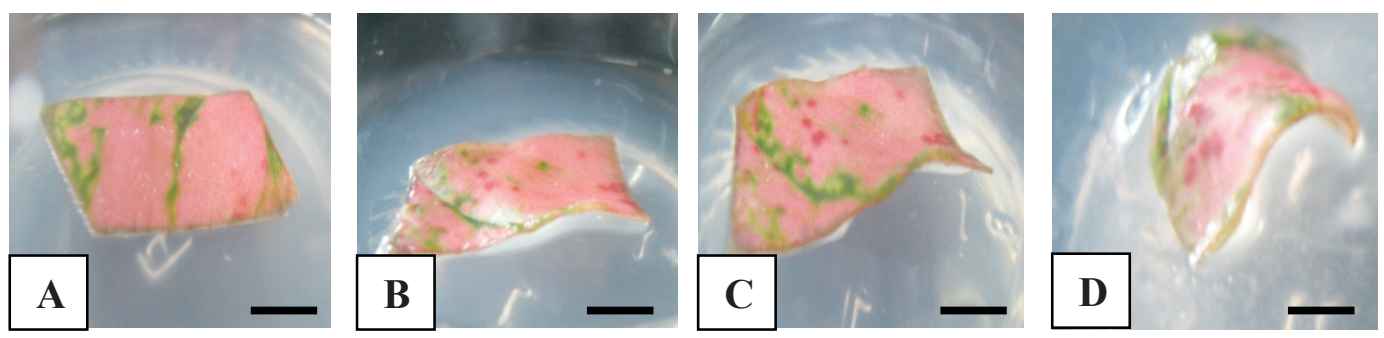

Gambar 2. Tahap perkembangan eksplan daun Aglaonema sp. var. Lady valentine. A.Tahap 0; B. Tahap 1; C. Tahap 2a; D.Tahap 3a. Skala $0,32 \mathrm{~cm}$.

tua atau lebih muda, tepi eksplan daun berwarna coklat, belum terbentuk kalus (2b), sedangkan pada perlakuan MS3 dan MS5 eksplan daun berkembang melengkung atau menggulung, warna eksplan daun tetap, belum terbentuk kalus, tepi daun eksplan berwarna coklat (3a). Pada perlakuan MS4 eksplan daun berkembang melengkung atau menggulung, warna eksplan daun berubah menjadi lebih tua atau lebih muda, terbentuk kalus pada tepi daun (3b) (Tabel 4, Gambar 3).

Tahap perkembangan eksplan daun mulai minggu pertama hingga minggu ke-16 dimulai tahap 0 , tahap 1 , tahap 2a, 2b, 3a, dan tahap 3b (Tabel 4, Gambar 3).

\section{Eksplan Daun yang Membentuk Kalus Selama 16 Minggu}

Pada penelitian ini, dari ketiga varietas eksplan daun Aglaonema sp. var. Siam Pearl, Aglaonema sp. var. Lady valentine, dan Aglaonema sp. var. Lipstik, jenis Aglaonema $s p$. var. Lipstik merupakan varietas yang dapat membentuk kalus pada perlakuan MS4 dan MS5. Pada perlakuan MS4, kalus mulai terbentuk pada minggu ke-14 hingga 16 minggu pengamatan, eksplan daun yang membentuk kalus sebanyak 2 ulangan. Pada media perlakuan MS5, hanya 1 eksplan daun yang dapat membentuk kalus mulai minggu ke-15 hingga 16 minggu.

Tabel 4. Modus perkembangan eksplan daun Aglaonema sp. var. Lipstik selama 16 minggu pada berbagai perlakuan zat pengatur tumbuh 3-indole-acetic acid dan 6-benzylaminopurine $(n=3)$.

\begin{tabular}{|c|c|c|c|c|c|c|c|c|c|c|c|c|c|c|c|c|}
\hline \multirow{2}{*}{ Perlakuan } & \multicolumn{16}{|c|}{ Tahap perkembangan eksplan daun selama 16 minggu masa kultur (minggu ke-) } \\
\hline & 1 & 2 & 3 & 4 & 5 & 6 & 7 & 8 & 9 & 10 & 11 & 12 & 13 & 14 & 15 & 16 \\
\hline MS 1 & 0 & 1 & 1 & 1 & 1 & 1 & 1 & 1 & $2 a$ & $2 a$ & $2 a$ & $2 a$ & $2 a$ & $2 a$ & $2 a$ & $2 a$ \\
\hline MS 2 & 0 & 0 & 1 & 1 & 1 & 1 & 1 & $2 a$ & $2 a$ & $2 a$ & $2 a$ & $2 b$ & $2 b$ & $2 b$ & $2 b$ & $2 b$ \\
\hline MS 3 & 0 & 1 & 1 & 1 & 1 & 1 & $2 a$ & $2 a$ & $2 a$ & $2 a$ & $2 a$ & $3 a$ & $3 a$ & $3 a$ & $3 a$ & $3 a$ \\
\hline MS 4 & 0 & 1 & 1 & 1 & 1 & $2 a$ & $2 a$ & $2 a$ & $2 a$ & $2 a$ & $3 a$ & $3 a$ & $3 a$ & $3 a$ & $3 b$ & $3 b$ \\
\hline MS 5 & 0 & 1 & 1 & 1 & 1 & $2 a$ & $2 a$ & $2 a$ & $2 a$ & $2 a$ & $2 a$ & $3 a$ & $3 a$ & $3 a$ & $3 a$ & $3 a$ \\
\hline
\end{tabular}
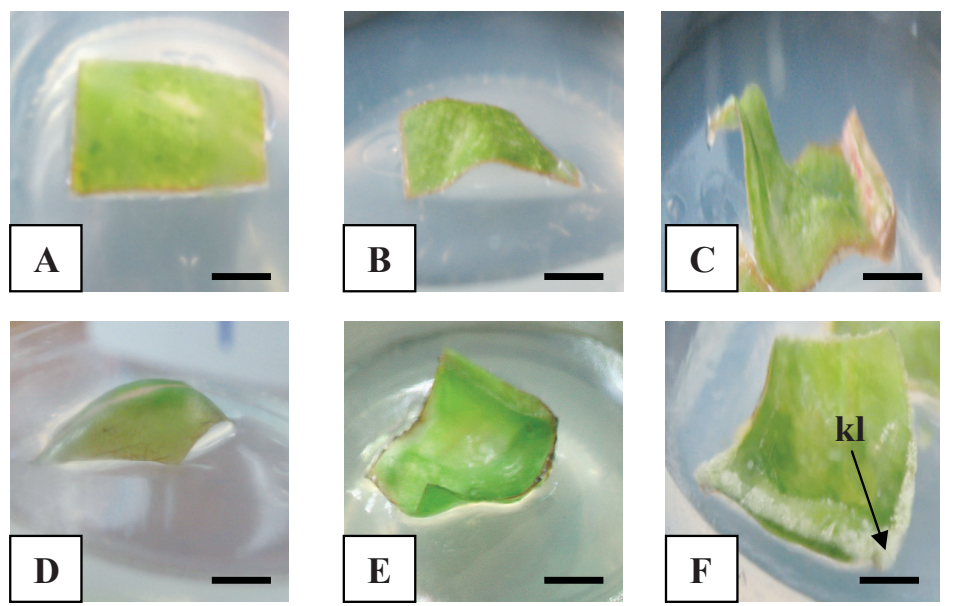

Gambar 3. Perkembangan eksplan daun Aglaonema sp. var. Lipstik. A. Tahap perkembangan 0, B. Tahap 1, C. Tahap 2a, D. Tahap 2b, E. Tahap 3a, F. Tahap 3b. kl. Kalus. Skala 0,34 cm. 


\section{PEMBAHASAN}

Pemberian kombinasi konsentrasi IAA dan BAP pada eksplan daun Aglaonema sp. var. Siam Pearl, Aglaonema $s p$. var. Lady Valentine, dan Aglaonema sp. var. Lipstik memberikan respon yang berbeda-beda pada masingmasing eksplan, yang ditunjukkan dengan helaian daun menjadi lebih besar, tulang daun membesar, helaian daun melengkung atau menggulung, tampak lebih tebal atau kaku, helaian daun dan tepi daun terjadi perubahan warna, sebagian helaian daun berwarna coklat, dan pada tepi daun atau bekas irisan terbentuk kalus pada Aglaonema sp. var. Lipstik.

Respon yang berbeda tersebut dipengaruhi oleh beberapa faktor, antara lain kombinasi zat pengatur tumbuh auksin dan sitokinin (Rashid et al., 2009; Abdelmageed et al., 2012; Shah et al., 2003). Pada budidaya jaringan sitokinin berfungsi untuk mengatur pertumbuhan dan morfogenesis, sedangkan auksin dapat merangsang pembesaran sel dan pertumbuhan akar (Katuuk, 1989; Lyndon, 1990). Faktor lain yang mempengaruhi perbedaan perkembangan eksplan adalah kadar hormon endogen pada eksplan. George dan Sherington (1992) menyatakan bahwa zat pengatur tumbuh pada konsentrasi tertentu mampu menghambat kerja hormon endogen dan dapat mengganggu pertumbuhan dan perkembangan sel.

Eksplan daun melengkung dan tulang daun membengkak disebabkan adanya pengaruh auksin dan tekanan turgor. Adanya auksin menyebabkan dinding sel mengendur dan merenggang. Pengenduran dinding sel ini terjadi karena adanya sekresi asam dengan mengaktifkan suatu enzim pada $\mathrm{pH}$ tertentu. Dengan merenggangnya sel, menyebabkan pemanjangan sel. Tekanan turgor terjadi apabila sel menyerap molekul air sebagai respon akan meningkatnya konsentrasi zat terlarut yang terdapat dalam vakuola, sehingga akan menyokong perluasan sel yang terjadi (Uno et al., 2001; Taiz dan Zieger, 1998). Aglaonema $s p$. var. Siam Pearl, Aglaonema sp. var. Lady valentine belum mampu membentuk kalus. Respon yang sama dialami eksplan daun Eucheuma cotonii dengan perlakuan 0-0,15 mg/l IAA (Sari, 2010).

Pada penelitian ini kalus terbentuk pada eksplan Aglaonema $s p$. var. Lipstik dengan perlakuan IAA $5 \mathrm{mg} / \mathrm{l}$ : $5 \mathrm{mg} / \mathrm{l}$ BAP dan IAA $8 \mathrm{mg} / \mathrm{l}: 5 \mathrm{mg} / \mathrm{l}$ BAP. Pada penelitian ini kalus mulai muncul pada daerah tulang daun eksplan dan menyebar keseluruh tepi eksplan menutupi luka bekas irisan (Gambar 3F). Munculnya kalus pada tulang daun disebabkan karena pada tulang daun terdapat pembuluh tapis yang merupakan perantara auksin dari pucuk dalam tubuh tanaman (Hendaryono dan Wijayani, 1994). Pembentukkan kalus disebabkan karena respons eksplan terhadap pelukaan (George dan Sherington, 1992) untuk menutup luka (Dodds dan Robberts 1982). Kalus mulai terbentuk dari bekas irisan eksplan yang mana sel-selnya berhenti bermitosis dan mulai membentuk kalus seperti pada Solanum nigrum L. (Sridar dan Naidu, 2011), Sonchus arvensi L. (Wahyuni et al., 2010), Trichosanthes dioica Roxb. (Komal, 2011), dan Anthurium digitatum (Reddy et al., 2011).

Aglaonema sp. var. Lipstik mampu membentuk kalus pada minggu ke-14 masa kultur. Lama waktu yang dibutuhkan untuk induksi kalus cukup lama dibandingkan dengan induksi kalus pada tanaman lain. Kalus mulai muncul minggu ke-2 masa kultur pada tanaman Sonchus arvensis, L. (Wahyuni et al., 2010), Cicer arietinum L. (Huda et al., 2003), Solanum nigrum L. (Sridar and Naidu, 2011), dan Michelia champaca (Abdelmageed et al., 2012), minggu ke-3 masa kultur pada Ananas comosus L. (Merr.) (Akbar et al., 2003) dan Cucumis melo L., (Melara et al., 2009), minggu ke 2-4 masa kultur pada Artemisia annua L. (Ganesan dan Paulsamy, 2011), minggu ke-4 pada Triticum aestivum L. (Shah et al., 2003), Anthurium digitatum dengan eksplan daun muda (Reddy et al., 2011) dan minggu ke 7-8 pada Anthurium digitatum dengan eksplan daun tua (Reddy et al., 2011).

Banyak faktor yang mempengaruhi keberhasilan induksi kalus, antara lain faktor genotipe dan zat pengatur tumbuh. Antara genotipe dan zat pengatur tumbuh sangat berkaitan erat memicu perkembangan eksplan. Genotipe tertentu akan cocok dengan kombinasi hormon tertentu, seperti induksi kalus pada 10 kultivar kapas, hanya 2 kultivar yang mampu membentuk kalus dengan perlakuan $2 \mathrm{mg} / 12,4-\mathrm{D}+0,1$ Kinetin, dan 10 kultivar mampu membentuk kalus dengan perlakuan $1 \mathrm{mg} / \mathrm{l} \mathrm{NAA}+2 \mathrm{mg} / \mathrm{l}$ Kinetin (Tripathy and Reddy, 2002). Penelitian Shirin et al., (2007) juga menunjukkan bahwa hanya 1 kultivar dari 4 kultivar Solanum tuberosum L. yang mampu membentuk kalus dengan perlakuan $0,5 \mathrm{mg} / \mathrm{l} \mathrm{NAA}+0,5 \mathrm{mg} / 1$ BAP. Induksi kalus pada 25 kultivar tanaman Festuca arundinacea Schreb. (Bai and Qu, 2000), 7 kultivar Cucumis melo L dengan perlakuan kombinasi konsentrasi 0-0,5 mg/l IAA + 0,1-1 mg/l BAP (Melara et al., 2009), 5 kultivar padi Jawa (Rachmawati and Anzai, 2006), 11 kultivar Melissa officinalis L. Dengan perlakuan IAA+BAP (Mohebalipour et al., 2012) dan 5 kultivar Triticum aestivum dengan perlakuan 2,4-D+Kinetin (Rashid et al., 2009) menunjukkan prosentase keberhasilan induksi kalus yang berbeda, baik dalam inisiasi maupun pertumbuhannya. Selanjutnya induksi kalus dengan perlakuan IAA + BAP juga berhasil pada tanaman Solanum nigrum L. (Sridar and Naidur, 2011), dan Michelia champaca (Abdelmageed et al., 2012). 
Kalus yang tumbuh pada eksplan daun Aglaonema $s p$. var. Lipstik berwarna bening, berbentuk globular, dan memiliki tekstur yang remah (friable). Tekstur kalus remah (friable) merupakan tekstur kalus yang mudah lepas atau hancur, dan berpotensi tumbuh menjadi embrio atau organ (embriogenik kalus atau organogenik kalus). Penelitian Ogata et al., (2005) menyatakan bahwa zat pengatur tumbuh IAA adalah auksin alami yang berperan penting dalam jalur embryogenesis somatik pada wortel. Perkembangan kalus friable atau kalus embriogenik pada Aglaonema $s p$. var. Lipstik merupakan tahapan perkembangan ke arah regenerasi tanaman melalui jalur indirect morfogenesis. Sesuai dengan beberapa penelitian bahwa IAA merupakan faktor penting dalam proses regenerasi, shoot regeneration tanaman Cucumis melo L. dengan perlakuan 0,5 mg/l BAP+ $0,05 \mathrm{mg} / \mathrm{l}$ IAA (Melara et al., 2009), maximum regeneration Triticum aestivum cv. Tatara dengan perlakuan $0,1 \mathrm{mg} / \mathrm{l}$ IAA +2 mg/l BAP (Rashid et al., 2009), root regeneration Trichosanthes dioica Roxb. dengan perlakuan 0,5 mg/l IAA (Komal, 2011), maximum regeneration Triticum aestivum L. dengan perlakuan $2 \mathrm{mg} / 1 \mathrm{BAP}+1 \mathrm{mg} / \mathrm{IAA}$ (Shah, 2003), root regeneration Anthurium andraeanum L. dengan perlakuan $0,5-1,5 \mathrm{mg} / 1$ IAA melalui jalur indirect morfogenesis.

Dari hasil dan pembahasan dapat diambil kesimpulan bahwa perlakuan kombinasi zat pengatur tumbuh IAA dan BAP menyebabkan perkembangan eksplan daun Aglaonema $s p$. var. Siam Pearl, Aglaonema sp. var. Lady Valentin dan Aglaonema sp. var. Lipstik menjadi melengkung, memanjang, dan menebal. Kombinasi 5 mg/l IAA dan $5 \mathrm{mg}$ BAP $\mathrm{mg} / \mathrm{l}$ merupakan konsentrasi terbaik untuk induksi kalus pada Aglaonema sp. var. Lipstik. Induksi kalus pada penelitian ini belum berhasil maksimal. Untuk meningkatkannya masih perlu dilakukan penelitian lagi dengan menggunakan hormon dan konsentrasi yang lebih bervariasi.

\section{UCAPAN TERIMA KASIH}

Penulis mengucapkan terima kasih kepada Bapak Mursyid sekeluarga yang telah berkenan menyediakan tanaman Aglaonema sebagai sumber eksplant.

\section{KEPUSTAKAAN}

Abadi HD, dan Kaviani B, 2010. In Vitro Proliferation of Important Medicinal Plant Aloe-A Method for Rapid Production. Australian Journal of Crop Science. 4(4): 216-222.

Abdelmageed, A.H.A., Faridah, Q.Z., Shuhada, N.K., dan Julia, A.A. 2012. Callus Induction and Plant Regeneration of
Michelia champaca L. (Magnoliaceae): A Multipurpose Tree. Journal of Medicinal Plants Research. 6(17): 33363344.

Akbar, A.M., Karmakar, K.B., dan Roy, K.S. 2003. Callus Induction and High-Frequency Plant Regeneration of Pineapple (Ananas comusus (L.) Merr.). Plant Tissue Culture. 13(2): 109-116.

Bai, Y., dan Qu, R. 2000. An Evaluation of Callus Induction and Plant Regeneration in Twenty-five Turf-Type Tall Fescue (Festuca arundinacea Schreb.) Cultivars. Grass and Forage Science. 55: 326-330.

Dodds, J.H., dan Robert, L.W. 1982. Experiment In Plant Tissue Culture. Cambridge University Press. London.

Ganesan, C.M., dan Paulsamy, S. 2011. Standardized Protocol for The In Vitro Culture of Artemisia annua L. - A medicinal Plant at High Altitudes of Nilgiris, The Western Ghats. Journal of Research in Biology. 3: 173-178.

George, E.F., dan Sherringthon, P.D. 1992. Plant Propagations By Tissue Culture. Eastern Press. England.

Hendaryono, D.P.S., dan Wijayani, A. 1994. Teknik Kultur Jaringan: Pengenalan dan Petunjuk Perbanyakan Tanaman Secara Vegetatif Modern. Penerbit Kanisius. Yogyakarta.

Hoesen, D.S.H., Witjaksono, dan Sukamto, L.A. 2008. Induksi Kalus dan Organogenesis Kultur In Vitro Dendrobium lineale Rolfe. Berita Biologi. 9(3): 333-341.

Huda, S., Islam R., Bari M.A., dan Asaduzzaman, M. 2003. Shoot Differentiation from Cotyledon Derived Callus of Chickpea (Cicer arietinum L.). Plant Tissue Culture. 13(1): 53-59.

Islam, M.M., Ahmed, M., dan Mahaldar, D. 2005. In Vitro Callus Induction and Plant Regeneration in Seed Explants of Rice (Oryza sativa L.). Journal of Agriculture and Biological Science. 1: 72-75.

Ibrahim, M.S.D., Rostiana, O., dan Khumaidah, N. 2010. Pengaruh Umur Eksplan Terhadap Keberhasilan Pembentukkan Kalus Embriogenik Pada Kultur Meristem Jahe (Zingibe officinale Rosc.). Jurnal Litri. 16 (1): 37-42.

Jahan, M.T., Islam, M.R., Khan, R., Mamun, A.N.K., Ahmed, G., dan Hakim, L. 2009. In Vitro Clonal Propagation of Anthurium (Anthurium andraeanum L.) Using Callus Culture. Plant Tissue Culture and Biotechnology. 19(1): 61-69.

Katuuk, J.R.P. 1989. Teknik Kultur Jaringan Dalam Mikropopagasi Tanaman. Depdikbud Dikti. Proyek Pengembangan Lembaga Pendidikan dan Tenaga Kependidikan. Jakarta.

Komal, R. 2011. Effect of BAP and IAA on Callus Formation and Plant Regenration in Pointed Gourd. Research Article. Biotechnology Bioinformation Bioenginerring. 1(1): 59-62.

Lyndon, R.F. 1990. Plant Development The Cellular Basis. Cambridge University Press. London.

Melara, M.V., Andres, M., dan Arias, G. 2009. Effect of BAP and IAA on Shoot Regeneration in Cotyledonary Explant of Costa Rican Melon Genotypes. Agronomia Costarricense. 33(1): 125-131. 
Mohebalipour, N., Aharizad, S., Mohammadi, S.A., Motallebiazar, A.R., dan Arefi, H.M. 2012 Effect of Plant Growth Regulators BAP and IAA on Micropropagation of Iranian Lemon Balm (Melisa officinalis L.) Landraces. Journal of Food Agriculture and Environment. 10(1): 280-286.

Murashige, T., dan Skoog, F. 1962. A. Revised Medium for Rapid Growth and Bioassays with Tobacco Tissue Culture. Physiologi Plantarum. 15: 473.

Ogata, Y. Itzuka, M., Nakayama, D., Ikeda, Kamada, H., dan Koshiba, T. 2005. Possible Involvement of Abcisic Acid in The Induction of Secondary Somatic Embryogenesis on Seed-Coat-Derived Carrot Somatic Embryos. Planta. 221: 417-423.

Rachmawati, Y. 2008. Induksi Kalus Dari Eksplan Daun Dan Tangkai Daun Wave Of Love (Anthurium plowmanii Croat.) Dengan Kombinasi Zat Pengatur Tumbuh Auksin Dan Sitokinin Secara In Vitro. Skripsi. Departemen Biologi. Fakultas Sains dan Teknologi. Universitas Airlangga. Surabaya.

Rachmawati, D., dan Anzai, H. 2006. Studies on Callus Induction, Plant Regeneration and Transformation of Javanica Rice Cultivars. Plant Biotechnology. 23: 521-524.

Rachmawati, D., Hosaka, T., Inoue, E., dan Anzai, H. 2004. Agrobacterium-mediated Tranformation of Javanica Rice cv. Rojolele. Bioscience Biotechnology Biochemistry. 68: $1193-1200$

Rashid, U., Ali, S., Ali, G.M., Ayub, N., dan Masood, M.S. 2009. Establishment of an Efficient Callus Induction and Plant Regeneration System in Pakistani Wheat (Triticum aestivum L.) Cultivars. Electronic Journal of Biotechnology. 12(3): $1-12$.

Reddy, J.M., Bopaiah, A.K., dan Abhilash, M. 2011. In Vitro Micropropagation of Anthurium digitatum, Using Leaf as Explant. Asian Journal of Pharmaceutical and Health Sciences. 3: 70-74.
Sari, T.W. 2010. Pengaruh Hormon Indole Acetic Acid (IAA) terhadap Induksi Kalus Eucheuma cotonii. Thesis. Institut Teknologi Sepuluh November. Surabaya.

Shah, M.I., Jabeen, M., dan llahi, I. 2003. In Vitro Callus Induction, Its Proliferation and Regeneration in Seed Explants of Wheat (Triticum aestivum L.) var. LU-26S. Pak. Journal Botany. 35(2): 209-217.

Shirin, F., Hossain, M., Kabir, M.F., Roy, M., dan Sarker, S.R. 2007. Callus Induction and Plant Regeneration from Internodal and Leaf Explant of For Potato (Solanum tuberosum L.). Journal of Agricultural Science. 3(1): 1-6.

Sridhar, T.M., dan Naidu, C.V. 2011. An Efficient Callus Induction and Plant Regeneration of Solanum nigrum L.- An Important Antiuicer Medicinal Plant. Journal of Phytology 3(5): 23-28.

Subono, M., dan Andoko, A. 2004. Meningkatkan Kualitas Aglaonema Sang Ratu Pembawa Rezeki. Penerbit Agromedia Pustaka. Jakarta.

Syahid, S.F., dan Kristina, N.N. 2007. Induksi dan Regenerasi Kalus Keladi Tikus (Typonium flagelliforme Lodd.) Secara In Vitro. Jurnal Litri. 13(4): 142-146.

Taiz, L., dan Zeiger, E. 1998. Plant Physiology. $2^{\text {nd }}$ edition. Sinauer Associates Inc. Sunderland.

Tripathy, S., dan Reddy, G.M. 2002. In Vitro Callus Induction and Plantlet Regeneration from Indian Cotton Cultivars. Plant Cell Biotechnology and Molecular Biology. 3: 137-142.

Uno, R., Storey, dan Moore, 2001. Principle Of Botany. Mc. Graw-Hill Compani es. USA.

Wahyuni, D.K., Utami, E.S.W., Ekasari, W., dan Wahyuni, T.S. 2010. Callus Induction of Sonchus arvensis L. and Its InVitro Antiplasmodial Activity. Proceeding of International Conference on Medicinal Plants. Pokjanas TOI-Widya Mandala Catholic University. Surabaya. 